\title{
USIA PERNIKAHAN TERHADAP TUMBUH KEMBANG BAYI DI PUSKESMAS KOMBOS KECAMATAN SINGKIL KOTA MANADO
}

\author{
Robin Dompas 1), Amelia Donsu²), Jenny Mandang3), Radiatul Adawiyah Muhammad4) \\ 1,2,3,4Dosen Jurusan Kebidanan Poltekkes Kemenkes Manado \\ Email: rob.dmps@gmail.com;
}

\begin{abstract}
The age of marriage is less than 14 years to 19 years compared to the percentage of married age more than 21 years is relatively high. Objective to find out the relationship between the age of marriage and the growth of infants in Kombos Health Center, Singkil District, Manado City.

Type of research is an analytical survey with 73 samples, sampling using probability sampling. The Sheet was check pre-questionnaire screening growth measured by looking at the baby's weight and height and baby's development (3, 6, 9 and 12 months) 10 number questions, Data analysis using test Chi-Square on significance $\alpha=0.05$.

The results Of the study indicate marriage age has no relationship with infant growth. Most marriage age more than 21 years have normal growth compared to marriage age less than 21 years, the results of statistical tests (value $\rho=0.188$ ) means that there is no relationship between marriage age and infant growth. There is a significant relationship between marriage age and infant development $(\rho=0,000)$, in this case the age of marriage can affect the development of the baby.
\end{abstract}

There is a positive correlation between the development of the baby and the growth of the baby.

Keywords: Age of Marriage; Growth and development; Kombos Health Center.

\section{ABSTRAK}

Usia menikah kurang dari 14 tahun sampai 19 tahun dibanding dengan persentase usia menikah lebih dari 21 tahun terbilang tinggi. untuk mengetahui Hubungan Usia Pernikahan Terhadap Tumbuh Kembang Bayi di Puskesmas Kombos Kecamatan Singkil Kota Manado.

Jenis penelitian yaitu survey analitik dengan 73 sampel, pengambilan sampel dengan cara probability sampling. Lembar cek list kuesioner pra skrinning pertumbuhan diukur dengan melihat berat badan dan tinggi badan bayi dan perkembangan bayi ( $3,6,9$ dan 12 bulan) 10 nomor pertanyaan, Analisis data menggunakan uji Chi - Square pada kemaknaan $a=0,05$.

Hasil penelitian menunjukkan usia pernikahan tidak memiliki hubungan dengan pertumbuhan bayi. Sebagian besar usia pernikahan lebih dari 21 tahun memiliki pertumbuhan yang normal dibandingkan dengan usia pernikahan kurang dari 21 tahun, hasil uji statistik (nilai $\rho=0,188$ ) berarti bahwa tidak ada hubungan antara usia pernikahan dengan pertumbuhan bayi. Ada hubungan yang bermakna antara usia pernikahan dengan perkembangan bayi (nilai $\rho=0,000$ ), dalam hal ini usia pernikahan dapat mempengaruhi perkembangan bayi. Simpulan terdapat hubungan positif antara perkembangan bayi dengan tumbuh kembang bayi

Kata kunci : Usia Pernikahan; Tumbuh kembang; Puskesmas Kombos.

\section{PENDAHULUAN}

Pernikahan yang deal untuk wanita adalah 21-25 tahun sementara pria 25-28 tahun. Karena diusia itu organ reproduksi wanita secara psikologis sudah berkembang dengan baik dan kuat serta siap untuk melahirkan keturunan secara fisik pun mulai matang. Sementara pria pada usia itu kondisi psikis dan fisiknya sangat kuat, hingga mampu menopang kehidupan keluarga untuk melindungi baik secara psikis emosional, ekonomi dan social.(Irianto $\mathrm{K}, 2015)$

Data dari Dinas Kesehatan Provinsi Sulawesi Utara yaitu pada tahun 2014, usia menikah kurang dari 14 tahun adalah 0,5 persen, sedangkan usia menikah antara 15 tahun sampai 19 tahun adalah 33,5 persen. ( Desiyanti I,2015)

Data yang diperoleh dari buku laporan persalinan ruang VK di Puskesmas Kombos Kecamatan Singkil Kota Manado, jumlah persalinan 
pada tahun 2016 sebanyak 318 ibu dengan usia persalinan $<21$ tahun sebanyak 66 ibu. Pada tahun 2017 jumlah persalinan sebanyak 414 dengan usia persalinan < 21 tahun sebanyak 62 ibu. Dan berdasarkan hasil studi awal dengan mewawancarai sepuluh ibu pada tanggal 6 Februari 2018 di Puskesmas Kombos Kecamatan Singkil Kota Manado di peroleh informasi bahwa empat ibu dengan usia $<19$ tahun mengalami masalahmasalah saat persalinan seperti BBLR, bayi tidak menangis spontan, dan persalinan macet.

Dampak pada pernikahan usia muda bagi wanita yang melangsungkan perkawinan di usia < 20 tahun, bila hamil akan mengalami gangguangangguan pada kandungannya dan banyak juga dari mereka yang melahirkan anak. Hal tersebut timbul dikarenakan belum matangnya organ reproduksi yang bisa mengalami gangguangangguan kesehatan. Dan juga berdampak terhadap anak-anaknya. Karena bagi wanita yang melangsungkan pernikahan pada usia muda yaitu dibawah 20 tahun, bila hamil akan mengalami gangguan pada kandungannya dan banyak juga dari mereka yang melahirkan anak premature. .(Irianto K,2015)

Penelitian ini bertujuan untuk mengetahui hubungan usia pernikahan terhadap tumbuh kembang bayi di puskesmas kombos kecamatan singkil kota manado.

\section{METODOLOGI PENELITIAN}

Penelitian ini adalah survei Analitik dengan pendekatan cross-sectional. dilakukan di
Puskesmas Kombos Kecamatan Singkil Kota Manado pada bulan januari sampai juli 2018. Populasi penelitian ini yaitu seluruh ibu yang mempunyai bayi di Puskesmas Kombos Kecamatan Singkil Kota Manado. Sampel berjumlah 73 bayi dengan teknik pengambilan sampel menggunakan purposive sampling dengan kriteria ibu yang memiliki bayi berusia 3, 6, 9, dan 12 bulan serta ibu yang datang di Puskesmas Kombos maupun di Posyandu. Instrument yang digunakan adalah ceklist. Analisis data dengan Uji chi - Square.

\section{HASIL DAN PEMBAHASAN}

Analisa Univariat

Tabel 1

Distribusi Responden Berdasarkan Usia

Pernikahan, Pertumbuhan Bayi, dan Perkembangan Bayi

\begin{tabular}{llcc}
\hline \multicolumn{1}{c}{ Variabel } & \multicolumn{1}{c}{ Kategori } & $\mathrm{f}$ & $\%$ \\
\hline \multirow{2}{*}{ Usia Pernikahan } & $<21$ tahun & 23 & 31,5 \\
& $\geq 21$ tahun & 50 & 68.5 \\
\hline Pertumbuhan & Kurus & 7 & 9,6 \\
Bayi & Normal & 66 & 90,4 \\
\hline \multirow{2}{*}{ Perkembangan } & Penyimpangan & 4 & 5,5 \\
Bayi & Meragukan & 32 & 43,8 \\
& Sesuai & 37 & 50,7 \\
\hline
\end{tabular}

Tabel 1 menunjukkan bahwa sebagian besar usia pernikahan $\geq 21$ tahun, sebagian besar bayi mempunyai pertumbuhan yang normal dan perkembangan yang sesuai

\section{Analisa Bivariat}

Tabel 2 Hubungan Usia Pernikahan dengan Pertumbuhan Bayi di Puskesmas Kombos Kecamatan Singkil Kota Manado

\begin{tabular}{ccccccccc}
\hline \multirow{2}{*}{ No. Usia Pernikahan } & \multicolumn{4}{c}{ Pertumbuhan Bayi } & \multicolumn{2}{c}{ Jumlah } & \multirow{2}{*}{ P value } \\
\cline { 3 - 7 } & & \multicolumn{2}{c}{ Normal } & \multicolumn{2}{c}{ Kurus } & & \multicolumn{2}{c}{$\%$} \\
\cline { 3 - 7 } & $\mathrm{N}$ & $\%$ & $\mathrm{~N}$ & $\%$ & $\mathrm{~N}$ & $\%$ & \\
\hline 1 & $<21$ tahun & 18 & 24,7 & 4 & 5,5 & 22 & 30,1 & \multirow{2}{*}{0,188} \\
\hline 2 & $\geq 21$ tahun & 48 & 65,8 & 3 & 4,1 & 51 & 69,9 & \\
\hline & Jumlah & 66 & 90,4 & 7 & 9,6 & 73 & 100 & \\
\hline
\end{tabular}

Data dari tabel 2 menunjukan bahwa sebagian besar bayi dari usia pernikahan $\geq 21$ tahun memiliki pertumbuhan yang normal sementara bayi yang usia pernikahan $<21$ tahun memiliki berat badan kurang (kurus). Uji statistik dengan menggunakan uji Chi-square didapatkan nilai $\rho=0,118(\rho<0,05)$ sehingga tidak terdapat hubungan antara usia pernikahan dengan pertumbuhan bayi.
Data dari tabel 3 menunjukan bahwa sebagian besar bayi dari usia pernikahan $\geq 21$ tahun memiliki perkembangan yang sesuai sementara perkembangan dari usia pernikahan < 21 tahun memiliki perkembangan yang menyimpang dan meragukan. Uji statistik dengan menggunakan uji Chi-square yang bermakna dengan nilai $\rho=0,000(\rho<0,05)$ sehingga terdapat hubungan antara usia pernikahan dengan perkembangan bayi. 


\section{Tabel 3 Hubungan Usia Pernikahan dengan Perkembangan Bayi di Puskesmas Kombos Kecamatan Singkil Kota Manado}

\begin{tabular}{|c|c|c|c|c|c|c|c|c|c|c|}
\hline \multirow{3}{*}{ No. } & \multirow{3}{*}{$\begin{array}{c}\text { Usia } \\
\text { Pernikahan }\end{array}$} & \multicolumn{6}{|c|}{ Perkembangan Bayi } & \multirow{2}{*}{\multicolumn{2}{|c|}{ Jumlah }} & \multirow{3}{*}{$\begin{array}{c}P \\
\text { value }\end{array}$} \\
\hline & & \multicolumn{2}{|c|}{ Penyimpangan } & \multicolumn{2}{|c|}{ Meragukan } & \multicolumn{2}{|c|}{ Sesuai } & & & \\
\hline & & $\mathrm{N}$ & $\%$ & $\mathrm{~N}$ & $\%$ & $\mathrm{~N}$ & $\%$ & $\mathrm{~N}$ & $\%$ & \\
\hline 1 & $<21$ tahun & 3 & 4,1 & 17 & 23,3 & 2 & 2,7 & 22 & 30,1 & 000 \\
\hline 2 & $\geq 21$ tahun & 1 & 1,4 & 15 & 20,5 & 35 & 47,9 & 51 & 69,9 & 0,000 \\
\hline Jun & & 4 & 5,5 & 32 & 43,8 & 37 & 50,7 & 73 & 100 & \\
\hline
\end{tabular}

\section{PEMBAHASAN}

Penelitian ini dilakukan dengan pengumpulan data pada ibu-ibu yang memiliki bayi umur 3, 6, 9 dan 12 bulan yang datang ke Puskesmas Kombos baik yang usia pernikahan < 21 tahun dan $\geq 21$ tahun dengan menggunakan daftar pertanyaan Kuesioner Pra Skrinning Pertumbuhan (KPSP).

Berdasarkan hasil penelitian menunjukkan bahwa dari ibu ibu yang menjadi responden terdapat 23 ibu yang berusia < 21 tahun hal ini disebabkan karena dari sebagian ibu yang menikah diusia dini alasannya adalah karena hamil sebelum nikah. Maka orang tua akan khawatir kena aib sehingga orang tua dari sang anak harus menikahkan anaknya untuk terhindar dari aib keluarga. Sebagaian orang tua berpendidikan menengah mendukung terjadinya pernikahan dini dengan alasan pernikahan dini dapat mencegah terjadinya zina dan hamil di luar nikah. (Anggraini F, Setyowati RN,2017)

Pernikahan yang ideal untuk wanita adalah 21-25 tahun sementara pria 25-28 tahun. Karena diusia itu organ reproduksi wanita secara psikologis sudah berkembang dengan baik dan kuat serta siap untuk melahirkan keturunan secara fisik pun mulai matang. Sementara pria pada usia itu kondisi psikis dan fisiknya sangat kuat, hingga mampu menopang kehidupan keluarga untuk melindungi baik secara psikis emosional, ekonomi dan social. .(Irianto $\mathrm{K}, 2015)$

Setelah dilakukan penelitian didapatkan sebagian besar bayi mempunyai tinggi badan $60-74$ $\mathrm{cm}$ yang berjumlah 65 bayi $(89,1 \%)$. Meskipun tidak terdapat hubungan antara usia pernikahan $<21$ tahun dengan pertumbuhan bayi. Akan tetapi usia pernikahan < 21 tahun bisa berdampak pada pertumbuhan bayi seperti kondisi anak saat lahir dapat terjadi BBLR (Barat Badan Lahir Rendah) yang bisa berpengaruh pada pertumbuhan bayi. Pasangan yang melangsungkan perkawinan pada usia muda dapat berdampak pada anak-anaknya seperti mengalami gangguan pada kandungannya dan juga banyak dari mereka yang melahirkan anak premature. .(Irianto K,2015)

Data yang didapatkan di puskesmas Kombos dari 73 bayi yang dijadikan sampel pada penelitian ini, sebagian besar bayi memiliki berat badan $<7$ kilogram yang berjumlah 47 bayi $(64,4 \%)$. Pertumbuhan bayi pada usia pernikahan sebagian besar adalah normal terutama bayi yang memiliki ibu $\geq 21$ tahun. Hasil penelitian ini sesuai dengan hasil sebelumnya menunjukkan bahwa wanita yang berusia relative muda masih dalam pertumbuhan dan perkembangan. Sehingga masih membutuhkan nutrisi yang lebih untuk pertumbuhannya. Apalagi wanita tersebut telah hamil dan bayi dikandungnya juga membutuhkan nutrisi untuk pertumbahan otak serta organ tubuh sehingga membutuhkan nutrisi yang lebih. (4)

Berdasarkan hasil penelitian yang didapatkan distribusi umur responden terbanyak adalah umur $\geq 21$ tahun sebanyak $68,5 \%$ dan terendah adalah umur $<21$ tahun sebanyak $31,5 \%$. Hal ini menunjukkan bahwa sebagian besar umur responden berada pada masa reproduksi dimana alat-alat reproduksi wanita sudah siap dan secara psikologis sudah berkembang dengan baik dan siap untuk melahirkan keturunan secara fisik pun mulai matang. .(Irianto K,2015)

Menurut tingkat pendidikan responden terbanyak adalah SMA/SMK sebanyak 54,8\% dan paling sedikit adalah perguruan tinggi sebanyak $5,5 \%$. Komplikasi persalinan adalah ibu yang kurangnya pengetahuan tentang pentingnya menjaga kehamilan. Hal ini sejalan dengan hasil penelitian menunjukan bahwa perempuan yang memiliki pengetahuan kurang berisiko 12,66 kali melakukan pernikahan usia dini dibandingkan dengan perempuan yang memiliki pengetahuan baik. Sejalan dengan teori mengungkapkan bahwa rendahnya tingkat pendidikan maupun tingkat pengetahuan orang tua, anak dan masyarakat menyebabkan adanya kecenderungan mengawinkan anaknya yang basih dibawah usia. .(Irianto K,2015) 
Dilihat dari jenis pekerjaan responden terbanyak adalah IRT sebanyak $76,8 \%$ dan terendah adalah mahasiswa dan PNS sebanyak $2,7 \%$. Kehadiran ibu dalam rumah mempunyai arti untuk perasaan keamanan dan kesejahteraan anak. Meskipun sang lbu pada saat bersamaan sibuk juga dengan pekerjaan rumah tangganya. Hal ini sejalan dengan hasil penelitian yang menunjukan bahwa ada hubungan yang signifikan antara status pekerjaan dengan perkembangan balita. Keterampilan ibu dalam deteksi dini tumbuh kembang sangat diperlukan karena dapat digunakan sebagai acuan dalam pemenuhan tumbuh kembang yang optimal. (Mira Susanti, Ramadhani EF,2010)

Hasil penilaian pertumbuhan bayi menurut status gizi didapatkan bahwa ibu yang usia pernikahan $\geq 21$ tahun mempunyai pertumbuhan bayi yang normal lebih banyak dari pada ibu yang usia pernikahan $<21$ tahun. Pada ibu yang berusia $\geq 21$ tahun sebesar $65,8 \%$ pertumbuhan bayinya normal dan $4,1 \%$ pertumbuhan bayinya kurang (kurus). Sedangkan pada ibu yang usia pernikahan $<21$ tahun diperoleh $24,7 \%$ dengan pertumbuhan bayinya normal dan $5,5 \%$ adalah pertumbuhan bayinya kurang (kurus).

Hasil penelitian pertumbuhan bayi antara ibu yang berusia $<21$ tahun dengan ibu yang berusia $\geq$ 21 tahun diketahui bahwa tidak terdapat perbedaan. Tidak adanya perbedaan pertumbuhan pada bayi mempunyai arti bahwa usia pernikahan $<21$ tahun dengan usia pernikahan $\geq 21$ tahun tidak mengalami gangguan pada pertumbuhan bayinya seperti ibu yang berusia $\geq 21$ tahun. Pertumbuhan dapat dihubungani oleh faktor orang tua seperti faktor genetic. Riwayat penyakit keluarga dapat diwariskan oleh gen yang terkait dengan gangguan tertentu, kromosom membawa gen yang menentukan karakteristik fisik, potensi intelektual, dan kepribadian.

Hasil penilaian pertumbuhan menurut status gizi didapatkan bahwa usia pernikahan $\geq 21$ tahun mempunyai pertumbuhan normal lebih banyak dari pada usia pernikahan $<21$ tahun. Pada usia $\geq 21$ tahun sebesar $65,8 \%$ pertumbuhan bayinya normal dan $4,1 \%$ pertumbuhan bayinya kurang (kurus), sedangkan usia pernikahan $<21$ tahun diperoleh $24,7 \%$ dengan pertumbuhan bayinya normal dan $5,5 \%$ adalah pertumbuhan bayinya kurang (kurus). Status gizi mencapai normal hubungan usia pernikahan dengan pertumbuhan bayi kemungkinan disebabkan oleh cara kemampuan ibu merawat dan mengasuh anaknya sehingga tumbuh kembang juga akan baik. ( Saputra WI, Irdawati,2010)
Berdasarkan hasil pemeriksaan perkembangan pada bayi usia 3, 6, 9, dan 12 bulan menggunakan Koesioner Pra Skrining perkembangan bayi, diperoleh usia pernikahan $\geq$ 21 tahun sebanyak 35 bayi $(47,9 \%)$ dengan perkembangan bayi sesuai umur, 15 bayi $(20,5 \%)$ mengalami keterlambatan pada perkembangan bayi (meragukan), dan 1 bayi $(1,4 \%)$ mengalami penyimpangan pada perkembangan bayi. Sedangkan usia pernikahan $<21$ tahun didapatkan 2 bayi $(2,7 \%)$ dengan hasil perkembangan normal, dan 17 bayi $(23,3 \%)$ mengalami keterlambatan (meragukan) serta 3 bayi $(4,1 \%)$ mengalami penyimpangan pada perkembangan bayi. Hubungan usia pernikahan dengan perkembangan bayi mungkin disebabkan oleh adanya faktor lain seperti pengetahuan orang tua baik ibu maupun ayah responden. Pengetahuan tentang bagaimana memberikan stimulasi kepada anaknya seperti membaca buku perkembangan anak yang dibeli di toko buku, ataupun berkonsultasi kepada dokter anak menjadikan modal pengetahuan bagi orang tua bagaimana memberikan stimulasi anak agar dapat berkembang sesuai dengan usianya. (D Astuti,2001)

Usia produktif merupakan usia dimana seseorang mencapai tingkat kematangan dalam hal produktifitasnya yang berupa rasional maupun motorik. ibu dalam kelompok umur produktif, dimana mereka telah memiliki kematangan dalam hal rasional maupun motorik. Hal ini sama halnya dengan hasil penelitian bahwa kematangan yang dimiliki oleh ibu menyebabkan kemampuan merawat dan mengasuh anaknya menjadi baik, sehingga tumbuh kembangnya juga baik. (Nurjanah,2001)

\section{SIMPULAN}

Usia minimum ibu 17 tahun, maximum ibu 42 tahun, pada umumnya bayi memiliki kategori normal dan masih ada kategori kurus. Sebagian besar bayi mempunyai perkembangan yang sesuai dengan usia, secara statistik tidak ada hubungan antara usia pernikahan dengan pertumbuhan bayi, terdapat hubungan usia pernikahan dengan perkembangan bayi.

\section{SARAN}

Usia Pernikahan seorang wanita sebaiknya dilakukan pada masa reproduksi sehingga saat terjadi kehamilan sudah termasuk dalam kategori tidak berisiko dalam reproduksainya 
DAFTAR PUSTAKA

Irianto K. Kesehatan Reproduksi (Reproductive Health) Teori dan Praktikum. Bandung: Alfabeta; 2015.

Desiyanti I. Faktor-faktor yang Berhubungan Terhadap Pernikahan Dini Pada Pasangan Usia Subur. JIKMU. 2015;5(2):270-80.

Anggraini $F$, Setyowati RN. Persepsi Orang Tua Terhadap Pernikahan Dini Di Desa Gedang Kulut Kecamatan Cerme Kabupaten Gresik Di Tinjau Dari Tingkat Pendidikan. Kaji Moral dan Kewarganegaraan. 2017;05(03):471-85.

Goli S, Rammohan A, Singh D. The Effect of Early Marriages and Early Childbearing on Women's Nutritional Status in India. Matern Child Heal J [Internet]. 2015;19(8):1864-80. Available from: https://web.b.ebscohost.com/

Siti Salamah. Faktor-faktor yang Berhubungan dengan Pernikahan Usia Dini Kecamatan Pulokulon Kabupaten Grobogan [Internet]. Universitas Negeri Malang; 2016. Available from: lib.unnes.ac.id

Mira Susanti, Ramadhani EF. Hubungan Status
Pekerjaan lbu Terhadap Tumbuh Kembang Balita di Jorong Biaro Nagari Biaro Gadang Kecamatan Ampek Angkek Kabupaten Agam Tahun 2010. J Kesehat Prima [Internet]. 2010;2(2):31-7. Available from:

http://garuda.ristekdikti.go.id/journal/article/ 495979

Saputra WI, Irdawati. Hubungan Tingkat Pengetahuan lbu dengan Tumbuh Kembang Bayi Premature Usia 6 Sampai 12 Bulan di Wilayah Kerja Puskesmas SeKecamatan Banjarsari. Ber IImu Keperawatan. 2010;4(1):50-7.

D Astuti. Perbedaan Tumbuh Kembang Anak 1-6 Bulan yang Diberikan Asi Eksklusif dengan yang tidak di Wilayah Kerja Puskesmas Karang Malang Sragen. 2010.

Nurjanah. Hubungan Terapeutik Perawat Klien (Kualitas Pribadi Sebagai Sarana). Yogyakarta: Bagian Penerbit Program Studi IImu Keperawatan Fakultas Kedokteran Universitas Gadjah Mada; 2001. 